\title{
ANALISIS POTENSI JEJAK KARBON LIMBAH CAIR DAN LISTRIK PADA PROSES PENYAMAKAN KULIT
}

\section{THE POTENTIAL CARBON FOOTPRINT ANALYSIS OF WASTEWATER AND ELECTRICITY IN THE LEATHER TANNING PROCESS}

\author{
Aditya Wahyu Nugraha1)*, Ono Suparno ${ }^{2)}$, dan Nastiti S. Indrasti ${ }^{2)}$ \\ ${ }^{1)}$ Departemen Teknologi Industri Pertanian, Institut Teknologi Sumatera \\ Jl. Terusan Ryacudu, Way Hui, Jati Agung, Lampung Selatan, Lampung, Indonesia \\ Email: aditya.nugraha@tip.itera.ac.id \\ ${ }^{2}$ Departemen Teknologi Industri Pertanian, Institut Pertanian Bogor \\ Jl. Raya Dramaga, Kampus IPB Dramaga Bogor 16680, Jawa Barat, Indonesia \\ Makalah: Diterima 12 Oktober 2020; Diperbaiki 29 November 2020; Disetujui 5 Desember 2020
}

\begin{abstract}
Leather is a product obtained from the conversion process of raw skin/hide into leather. The process generate a number of wastes with a high pollutant content, especially waste water. The waste contributes to the formation of carbon emission. Awareness on environmental sustainability also requires the industry to improve its production system to make it more eco-friendly. Improvements will increase production and the industry reputation. Before making improvements to the production system, it is necessary to carry out an analysis related to the carbon emissions produced in producing a product. The objectives of this study were to calculate carbon emission (carbon footprint) that generates in the leather tannery process and to give alternative strategy for the environmental improvement. The research used primary data and secondary data. This research was carried out with the processes identification, carbon emission sources identification, an analysis of the carbon emission potential amount, and a study of strategies to minimize carbon formation in the tannery. The results of the analysis showed that electricity and wastewater were sources of carbon in the production process of leather. The total of carbon emission formed in the leather tanning process was 1,692.17 $\mathrm{kg} \mathrm{CO}$ eq per batch, where wastewater contributed more than electricity. Further analysis showed that $1 \mathrm{~m}^{2}$ of leather produced $8.08 \mathrm{~kg} \mathrm{CO}_{2}$ eq of carbon. The strategies that can be taken to reduce carbon emissions are engineering processes, material substitution, and using eco-friendly materials.
\end{abstract}

Keywords: carbon footprint, leather, tannery

\section{ABSTRAK}

Kulit samak merupakan produk yang diperoleh dari proses konversi kulit segar menjadi kulit samak. Proses konversi tersebut menghasilkan sejumlah limbah dengan kandungan polutan yang tinggi, khususnya adalah limbah cair. Limbah tersebut berkontribusi terhadap terbentuknya emisi karbon. Kesadaran akan keberlanjutan lingkungan juga menuntut industri untuk membenahi sistem produksi agar lebih ramah lingkungan. Perbaikan akan meningkatkan produksi dan reputasi industri tersebut. Sebelum melakukan perbaikan pada sistem produksi, maka perlu dilakukan analisis terkait emisi karbon yang dihasilkan dalam menghasilkan suatu produk. Tujuan penelitian ini adalah untuk menghitung emisi karbon yang terbentuk pada proses penyamakan kulit dan memberikan strategi perbaikan yang dapat dilakukan. Penelitian ini menggunakan data primer dan skunder. Penelitian diawali dengan identifikasi proses, sumber emisi karbon, analisis potensi jumlah emisi karbon, dan kajian strategi untuk meminimasi terbentuknya karbon di industri penyamakan kulit. Hasil analisis menunjukkan bahwa listrik dan limbah cair merupakan sumber emisi karbon di proses produksi kulit samak. Total emisi karbon yang terbentuk pada proses penyamakan kulit adalah $1.692,17 \mathrm{~kg} \mathrm{CO}_{2 \text { eq }}$ per batch, dengan limbah cair berkontribusi lebih besar dibandingkan listrik. Analisis lanjut menunjukkan bahwa $1 \mathrm{~m}^{2}$ kulit samak membentuk emisi karbon sebanyak $8,08 \mathrm{~kg} \mathrm{CO}_{2 \text { eq. }}$. Strategi yang dapat dilakukan untuk mengurangi emisi karbon adalah merekayasa proses, subtitusi bahan, dan penggunaan bahan yang ramah lingkungan.

Kata kunci: industri penyamakan kulit, jejak karbon, kulit samak

\section{PENDAHULUAN}

Pemanasan global merupakan fenomena meningkatnya suhu permukaan bumi akibat adanya efek rumah kaca. Fenomena ini menyebabkan terjadinya perubahan iklim global, sehingga memberikan efek lanjutan berupa mencairnya es di kutub, kemudian terjadinya kenaikan ketinggian permukaan laut, lalu mengganggu sektor pertanian dan akhirnya melumpuhkan kegiatan perekonomian suatu negara (Darwin, 2004; Abdallah dan Elshennawry, 2013). Selain itu, meningkatnya $\mathrm{CO}_{2}$ pada atmosfer juga dapat menyebabkan terjadinya asidifikasi samudra (Harrould-Kolieb et al., 2010). 
Emisi gas rumah kaca (GRK) merupakan faktor yang menyebabkan terjadinya pemanasan global. Menurut IPCC (2006), gas-gas utama yang dikategorikan sebagai GRK dan mempunyai potensi penyebab terjadinya pemanasan global adalah $\mathrm{CO}_{2}, \mathrm{CH}_{4}$, dan $\mathrm{N}_{2} \mathrm{O}$. Gas $\mathrm{CO}_{2}$ mempunyai andil sebanyak $50 \%$ dan $\mathrm{CH}_{4}$ sebanyak $20 \%$ dari total GRK.

Industri merupakan salah satu penyumbang karbon dari enam sektor penghasil karbon terbesar, yakni kehutanan, pertanian, energi, industri, dan limbah (Purwanta, 2010). Salah satu industri yang memiliki potensi terhadap terbentuknya karbon dalam jumlah besar adalah industri penyamakan kulit. Industri penyamakan kulit merupakan industri yang bergerak dalam proses pemanfaatan limbah kulit menjadi kulit tersamak. Penelitian Nugraha et al. (2018) menunjukkan bahwa industri penyamakan kulit menghasilkan limbah dalam jumlah yang cukup besar, yakni sekitar 29,3 $\mathrm{m}^{3}$ limbah cair dan 1,75 ton (bb) limbah padat dari 1,5 ton kulit garaman yang digunakan. Sementara itu, menurut Bhargavi et al. (2015) dan Sekaran et al. (2007), 1 kg kulit akan menghasilkan limbah cair sebesar 30-35 liter dan limbah padat sebanyak $0,7 \mathrm{~kg}$.

Berdasarkan penelitian Alimuddin et al. (2018), penggunaan listrik yang bersumber dari fosil pada proses produksi menyumbang terbentuknya emisi. Hal tersebut dikarenakan adanya kebutuhan sumber pembangkit energi untuk menghasilkan energi penggerak dalam proses produksi. Umumnya sumber pembangkit energi dapat berasal dari minyak bumi dan batu bara. Menurut Radu et al. (2013), minyak bumi dan batu bara menghasilkan emisi karbon dioksida dalam jumlah besar saat proses pembakaran untuk menghasilkan energi. Selain itu, juga terbentuk gas lain seperti $\mathrm{CH}_{4}, \mathrm{~N}_{2} \mathrm{O}, \mathrm{HFC}, \mathrm{PFC}$, dan $\mathrm{SF}_{6}$ yang juga dapat dikonversi menjadi $\mathrm{CO}_{2}$ ekuivalen. Chai et al. (2015) dan Robescu dan Presura
(2017) menyatakan bahwa limbah cair juga dapat menimbulkan emisi karbon. Hal itu disebabkan oleh adanya proses dekomposisi nutrien yang ada pada limbah cair. Proses dekomposisi tersebut menghasilkan gas berupa metan dan karbon dioksida. Oleh karena itu, tujuan dari penelitian ini adalah untuk menganalisis potensi emisi karbon yang akan terbentuk pada setiap tahapan penyamakan kulit, sehingga dapat memberikan strategi yang dapat meminimalkan terbentuknya emisi karbon pada tahap penyamakan kulit.

\section{BAHAN DAN METODE}

\section{Tahapan dan Ruang Lingkup Penelitian}

Penelitian ini dilakukan di salah satu industri penyamakan kulit di Garut, Jawa Barat, Indonesia. Penelitian dilakukan dalam beberapa tahapan, yakni pemilihan industri penyamakan kulit menggunakan metode purposive sampling (Teddlie dan Yiu, 2007), identifikasi proses penyamakan kulit, analisis potensi jejak karbon, dan alternatif startegi untuk menurunkan jejak karbon. Analisis hanya dilakukan pada bagian proses penyamakan di industri penyamakan kulit (Gambar 1).

\section{Pengumpulan Data}

Data yang digunakan pada penelitian ini adalah data primer dan data sekunder. Data primer merupakan data yang diperoleh dari pengukuran langsung dari proses penyamakan kulit, yakni dengan menggunakan pendekatan aliran bahan dan lama proses dari setiap tahap proses penyamakan. Data sekunder diperoleh dari wawancara pemilik industri untuk mengetahui jenis peralatan yang digunakan selama proses penyamakan.

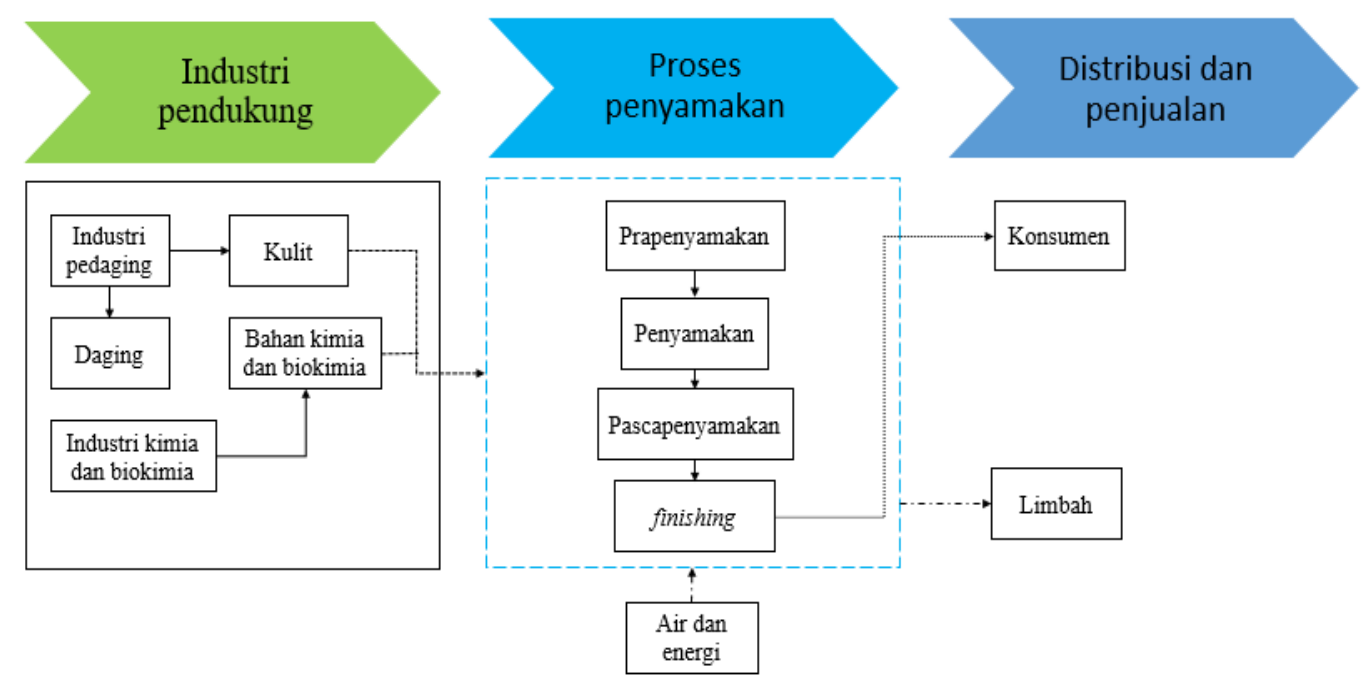

Gambar 1. Ruang lingkup penelitian 
Data yang dikumpulkan dalam pengukuran langsung meliputi daya alat, durasi penggunaan alat, jumlah limbah cair, dan karakteristik limbah cair. Estimasi perhitungan karbon dioksida dihitung dari penggunaan energi dan limbah cair yang terbentuk. Data yang diperoleh kemudian digunakan untuk menghitung potensi emisi karbon yang dihasilkan dari proses penyamakan kulit.

\section{Analisis Potensi Jejak Emisi Karbon}

Perhitungan jejak karbon menggunakan perhitungan emisi Gas Rumah Kaca (GRK); emisi karbon yang dihitung pada penelitian ini dalam bentuk karbon dioksida. Analisis emisi karbon pada penelitian ini dilakukan pada listrik dan limbah cair yang terbentuk selama proses produksi. Formula yang digunakan adalah sebagai berikut.

Menurut Putt dan Bahtia (2002), perhitungan emisi $\mathrm{CO}_{2}$ dari listrik menggunakan persamaan (1) berikut ini:

$$
\text { Emisi } \mathrm{CO}_{2 \text { (listrik) }}=\mathrm{Q}_{\mathrm{L}} \times \mathrm{FE}
$$

dengan:

$$
\begin{aligned}
\mathrm{Q}_{\mathrm{L}}= & \text { konsumsi listrik }(\mathrm{kWh}) \\
\mathrm{FE}= & \text { faktor emisi }(0,84 \mathrm{~kg} \mathrm{CO} / \mathrm{kWh})(\mathrm{ESDM} \\
& \text { 2016) }
\end{aligned}
$$

Emisi $\mathrm{CH}_{4}$ yang berasal dari limbah cair dapat dilakukan dengan perhitungan yang berasal dari COD yang terbentuk. Berdasarkan IPCC (2006), $\mathrm{CH}_{4}$ yang berasal dari limbah cair dihitung melalui persamaan (2) adalah sebagai berikut.

Emisi $\mathrm{CH}_{4(\text { limbah cair) }}=\mathrm{V}_{\mathrm{LC}} \times \mathrm{C} \times \mathrm{FE}$

dengan:

$$
\begin{array}{ll}
\mathrm{V}_{\mathrm{CL}} & =\text { volume limbah cair }(\mathrm{L}) \\
\mathrm{C} & =\text { nilai COD }(\mathrm{mg} / \mathrm{L}) \\
\mathrm{FE} & =\text { faktor emisi }(0,025 \mathrm{~kg} \mathrm{CH} / \mathrm{kg} \mathrm{COD})
\end{array}
$$

Menurut IPCC (2006), $\mathrm{CH}_{4}$ (gas metan) memiliki nilai Global Warming Potential (GWP) sebesar $23 \mathrm{~kg} \mathrm{CO}_{2}$ eq. Nilai GWP ini relatif sama dengan $\mathrm{CO}_{2}$ maka persamaannya sebagai berikut.

$$
\begin{gathered}
1 \mathrm{~kg} \mathrm{CH}_{4}=23 \mathrm{~kg} \mathrm{CO}_{2} \text { eq } \\
1 \mathrm{~kg} \mathrm{~N}_{2} \mathrm{O}=298 \mathrm{~kg} \mathrm{CO}_{2} \text { eq }
\end{gathered}
$$

Total emisi karbon yang dihasilkan dihitung dengan menggunakan persamaan 3 sebagai berikut.

Total Emisi: $\left(\right.$ Emisi $\left.\mathrm{CH}_{4} \times 23\right)+$ Emisi $\mathrm{CO}$.

Perhitungan jejak karbon pada kulit samak yang dihasilkan dilakukan dengan membagi jumlah total karbon dengan kulit samak yang dihasilkan, maka persamaan 4 sebagai berikut.

$$
\mathrm{JK}=\frac{T C}{T L}
$$

dengan:

$$
\begin{array}{ll}
\mathrm{JK} & =\text { Jejak karbon }\left(\mathrm{kg} \mathrm{CO} \mathrm{CO}_{2 \text { eqv }} \text { per } \mathrm{m}^{2}\right) \\
\mathrm{TC} & =\text { Total karbon }\left(\mathrm{kg} \mathrm{CO} \mathrm{CO}_{2 \text { eqv }}\right) \\
\mathrm{TL} & =\text { Jumlah kulit }\left(\mathrm{m}^{2)}\right.
\end{array}
$$

\section{Alternatif Strategi Penurunan Jejak Karbon}

Penentuan alternatif strategi menurunkan jejak karbon di industri penyamakan kulit dilakukan dengan survey beberapa industri untuk membandingkan teknologi yang dapat diadobsi dan kajian pustaka terkait rekayasa proses penyamakan kulit yang berpotensi untuk menurunkan jumlah emisi karbon yang terbentuk.

\section{HASIL DAN PEMBAHASAN}

\section{Identifikasi Proses Penyamakan Kulit}

Penyamakan adalah proses konversi protein kulit mentah menjadi kulit samak yang stabil, tidak mudah membusuk, dan cocok untuk beragam keunaan (Suparno et al., 2008). Secara umum proses penyamakan kulit terbagi tiga, yaitu prapenyamakan (beamhouse), penyamakan (tanning), dan pascapenyamakan (post-tanning). Pada proses prapenyamakan terdapat beberapa tahap, diantaranya adalah soaking, liming, splitting, deliming, bating, dan pickling. Tujuan proses prapenyamakan adalah untuk mempersiapkan kulit segar/mentah siap untuk disamak menggunakan bahan penyamak. Tahap penyamakan merupakan proses penambahan bahan penyamak ke dalam kulit. Pada proses penyamakan juga terdapat proses tambahan, yaitu sammying. Sementara itu, proses pascapenyamakan adalah proses yang bertujuan untuk menyempurnakan kulit samak yang sudah terbentuk, seperti memberikan warna dasar dan pelapisan permukaan kulit. Alur proses penyamakan kulit dapat dilihat pada Tabel 1 .

Selama proses konversi kulit mentah menjadi kulit samak, teridentifikasi bahwa hampir semua tahap menggunakan listrik dan menghasilkan limbah air (Tabel 1). Whittington (2002) dan Bello et al. (2018) menyatakan bahwa listrik yang bersumber dari fosil merupakan penghasil karbon. Sementara itu, limbah cair juga merupakan sumber penghasil karbon (Vijayan et al., 2017; Gupta dan Singh, 2012). Selain listrik dan limbah cair, pada proses produksi kulit samak juga dihasilkan limbah padat, namun limbah tersebut digunakan oleh industri atau pihak lain sebagai bahan baku sehingga tidak dihitung sebagai sumber emisi karbon.

Listrik merupakan sumber energi yang digunakan hampir di seluruh rantai proses produksi kulit samak. Hal ini dikarenakan listrik sebagai sumber energi penggerak bagi peralatan yang digunakan. Dari identifikasi yang telah dilakukan, peralatan yang digunakan pada setiap tahapan penyamakan kulit terdiri atas pompa air, molen atau drum, mesin sammying, mesin shaving, toggle dryer, dan roll coating (Tabel 2). Total penggunaan listrik proses penyamakan kulit adalah 441,64 kWh dan 
tahap tanning merupakan tahap yang paling banyak mengkonsumsi listrik dari total konsumsi listrik di seluruh proses penyamakan kulit (Tabel 2). Menurut World Nuclear Association (2020), listrik yang dihasilkan dari bahan bakar fosil menyumbang gas rumah kaca saat proses konversi menjadi energi. Pembakaran bahan bakar fosil menghasilkan karbon dioksida (IEA 2011).

Limbah cair merupakan limbah yang sangat dominan terbentuk di industri penyamakan kulit. Hal tersebut karena hampir semua tahapan proses penyamakan kulit menggunakan air (Nugraha et al., 2018). Tingginya limbah cair yang terbentuk berkorelasi terhadap penggunaan air. Ludvik (1996) menyatakan bahwa 1 ton kulit akan menghasilkan limbah cair sebanyak $45-50 \mathrm{~m}^{3}$. Dari identifikasi yang telah dilakukan menunjukkan bahwa tahapan soaking dan liming merupakan tahapan yang paling banyak menghasilkan limbah cair (Tabel 2).

Limbah cair di industri penyamakan kulit banyak mengandung senyawa organik. Senyawa yang ada pada limbah cair tersebut berperan dalam pembentukan gas karbon dioksida dan metan di lingkungan. Hasil dari penelitian lain mendukung bahwa limbah cair berkontribusi terhadap terbentuknya gas rumah kaca (Thangarajan et al., 2012; USEPA, 2014; Campos et al., 2016). Salah satu gas yang terbentuk adalah karbon dioksida.

Tabel 1. Tahapan penyamakan kulit dan jenis sumber emisi karbon

\begin{tabular}{cll}
\hline \multicolumn{1}{c}{ Proses } & \multicolumn{1}{c}{ Sub proses } & \multicolumn{1}{c}{ Jenis sumber emisi karbon } \\
\hline & Soaking & Listrik dan limbah cair \\
& Liming & Listrik dan limbah Cair \\
Beamhouse / prapenyamakan & Splitting & Listrik \\
& Deliming dan bating & Listrik dan limbah cair \\
& Pickling & Listrik \\
& Tanning & Listrik dan limbah cair \\
Tanning / penyamakan & Sammying & Listrik dan limbah cair \\
& Shaving & Listrik \\
& Wetting back 1 & Listrik dan limbah cair \\
& Retanning, dyeing, fatliquoring & Listrik dan limbah cair \\
& Hanging 1 & Limbah cair \\
& Wetting back 2 & Listrik dan limbah cair \\
Posttaning / pascapenyamakan & Re Fat Topping & Listrik dan limbah cair \\
& Hanging 2 & Limbah cair \\
& Stacking & Listrik \\
& Toggling & Listrik \\
& Coating & Listrik dan limbah cair \\
\hline
\end{tabular}

Tabel 2. Identifikasi potensi jejak emisi karbon pada peralatan dan limbah cair penyamakan kulit per batch

\begin{tabular}{llcc}
\hline \multicolumn{1}{c}{ Proses } & \multicolumn{1}{c}{ Alat / mesin } & $\begin{array}{c}\text { Konsumsi energi } \\
(\mathbf{k W h})\end{array}$ & Limbah cair (L) \\
\hline Soaking & Molen / drum dan pompa air & 20,15 & $10.789,65$ \\
Liming & Molen / drum dan pompa air & 20,79 & $12.954,74$ \\
Splitting & Mesin splitting & 29,84 & - \\
Deliming dan bating & Molen / drum dan pompa air & 12,34 & $6.058,60$ \\
Pickling & Molen / drum dan pompa air & 62,03 & 0,00 \\
Tanning & Molen / drum & 74,60 & $1.496,36$ \\
Sammying & Mesin sammying & 11,00 & 616,49 \\
Shaving & Mesin shaving & 37,3 & - \\
Wetting back 1 & Molen / drum dan pompa air & 5,75 & $1.297,85$ \\
Retanning, dyeing, & Molen / drum dan pompa air & 76,56 & $3.474,14$ \\
fatliquoring & & - & 284,45 \\
Hanging 1 & - & 7,06 & $1.839,32$ \\
Wetting back 2 & Molen / drum dan pompa air & 15,18 & 687,38 \\
Re Fat Topping & Molen / drum dan pompa air & - & 269,38 \\
Hanging 2 & - & 37,3 & - \\
Stacking & Molen / drum & 22,38 & - \\
Togling & Toggle dryer & 9,36 & 135,23 \\
Coating & Roll coating & 441,64 & $39.489,98$ \\
\hline
\end{tabular}




\section{Analisis Jejak Karbon}

Berdasarkan persamaan 3, hasil analisis menunjukkan bahwa total emisi karbon yang terbentuk selama proses produksi sebesar $1.692,17 \mathrm{~kg}$ $\mathrm{CO}_{2 \text { eq }}$ per batch. Limbah cair lebih banyak menghasilkan emisi karbon dibandingkan penggunaan listrik (Tabel 3). Banyaknya limbah cair yang terbentuk dan kandungan bahan organik pada limbah cair berpengaruh terhadap emisi karbon yang dihasilkan. Sementara itu, penggunaan listrik pada setiap proses penyamakan kulit tidak setinggi limbah cair. Hal ini disebabkan adanya perbedaan faktor perhitungan emisi dari listrik dan limbah cair. Perhitungan emisi pada listrik dipengaruhi oleh daya alat, durasi pemakaian alat, dan sumber listrik yang digunakan.

Tabel 3. Potensi total emisi karbon dari listrik dan limbah cair

\begin{tabular}{lc}
\hline $\begin{array}{c}\text { Sumber } \\
\text { Karbon }\end{array}$ & $\begin{array}{c}\text { Total karbon dioksida } \\
\text { ekuivalen } \\
\text { (kg CO2 eq per } \text { batch })\end{array}$ \\
\hline Listrik & 372,74 \\
Limbah Cair & $1.319,43$ \\
\hline
\end{tabular}

Gambar 2 menunjukkan bahwa emisi dari setiap tahapan proses penyamakan kulit menghasilkan emisi yang berbeda-beda. Pada Gambar 2 dapat dilihat bahwa emisi karbon terbesar dari penggunaan listrik dari setiap tahapan memiliki jumlah yang berbeda-beda. Hasil analisis menunjukkan bahwa tahap hanging 1 dan hanging 2 merupakan tahap yang tidak menghasilkan emisi karbon. Hal tersebut karena pada tahap tersebut tidak menggunakan listrik. Tahap hanging bertujuan untuk mengurangi kadar air pada kulit samak. Hanging hanya mengandalkan panas matahari. Sementara itu, pada tahap yang lain menghasilkan emisi karbon. Emisi karbon yang paling banyak terbentuk pada tahap tanning dan retanning, dyeing, dan fatliquoring, yakni sebesar $62,96 \mathrm{~kg} \mathrm{CO} \mathrm{CO}_{2}$ eq per batch dan $64,62 \mathrm{~kg} \mathrm{CO}_{2}$ eq per batch. Sementara itu, tahap yang sedikit menghasilkan emisi pada tahap wetting back 1, yaitu sebesar $4,85 \mathrm{~kg} \mathrm{CO}_{2}$ eq per batch. Perbedaan emisi yang dihasilkan setiap tahapan ini dikarenakan adanya perbedaan daya antara beberapa jenis alat dan durasi penggunaan alat selama proses produksi.

Gambar 3 menunjukkan potensi emisi karbon yang timbul dari setiap tahap penyamakan kulit yang bersumber dari limbah cair. Pada proses penyamakan kulit terdapat tahapan yang tidak menghasilkan limbah cair. Hal itu disebabkan tidak adanya penggunaan air dan pembuangan limbah cair pada proses tersebut. Beberapa tahapan yang tidak menghasilkan limbah cair terdapat pada pada splitting, pickling, shaving, hanging, togling, dan stacking.

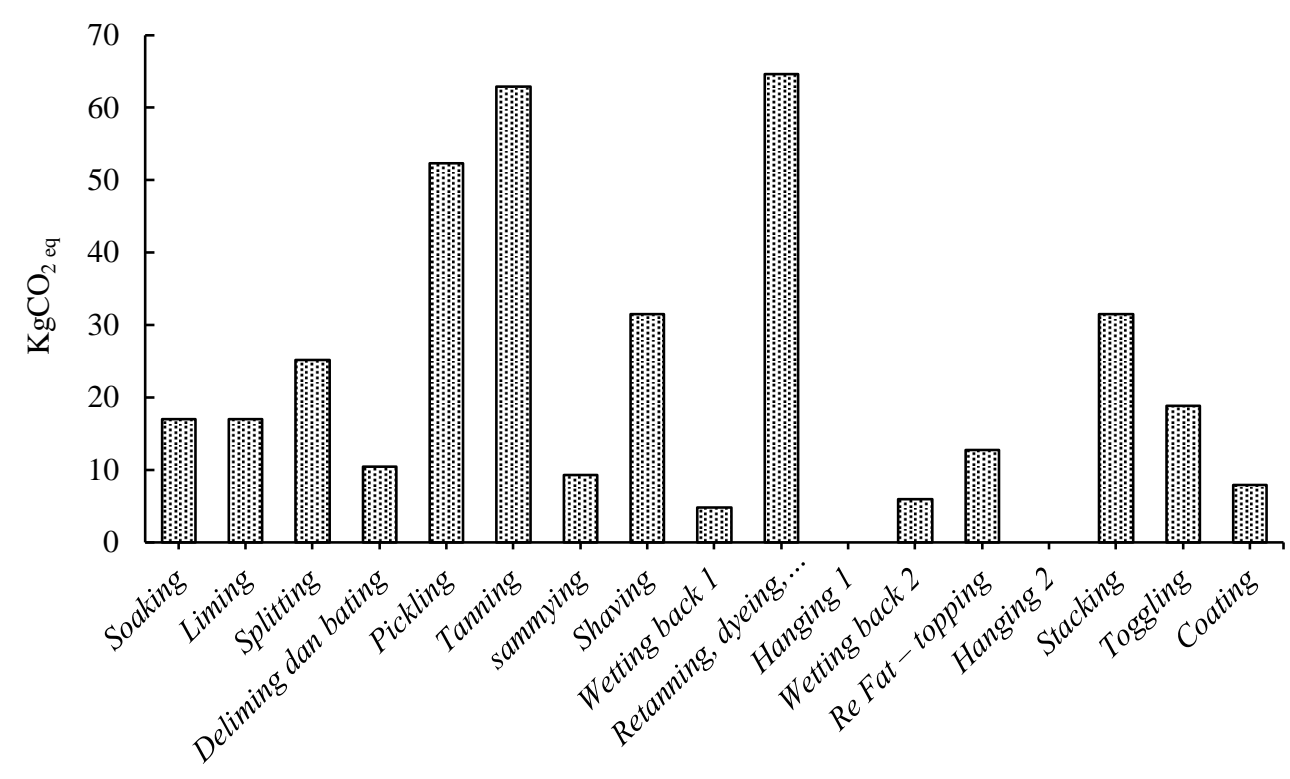

Gambar 2. Sebaran emisi $\mathrm{CO}_{2}$ pada proses penyamakan kulit dari sumber listrik 


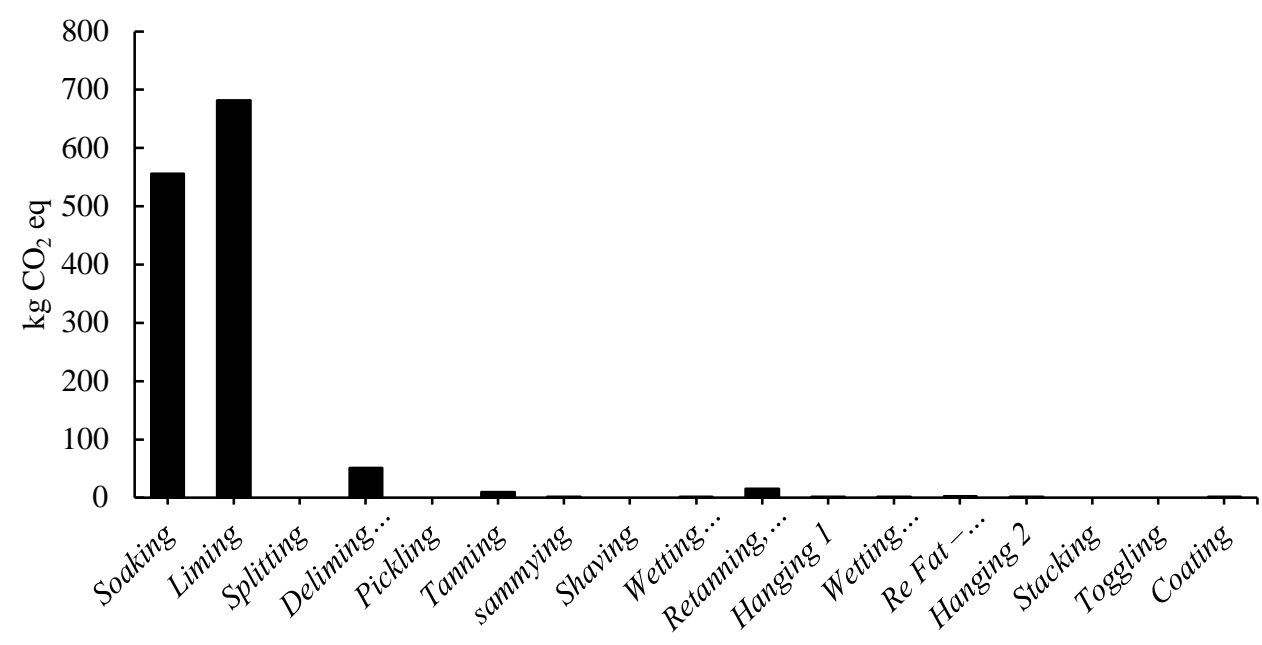

Gambar 3. Sebaran emisi $\mathrm{CO}_{2}$ pada proses penyamakan kulit dari sumber limbah cair

Karbon dioksida merupakan salah satu emisi yang dihasilkan dari proses dekomposisi bahan organik pada limbah cair, baik secara aerobik maupun anaerobik (Gerardi, 2003). Reaksi yang terjadi pada fermentasi bahan organik dalam pembentukan asam dan gas metan melibatkan banyak reaksi percabangan yang juga menghasilkan karbon dioksida (Gerardi, 2003). Emisi gas metana, suhu, bahan organik, dan $\mathrm{pH}$ berpengaruh terhadap respirasi dan konsentrasi karbon dioksida di suatu lingkungan perairan (Sobek et al., 2005). Analisis aliran bahan menunjukkan bahwa kulit samak yang dihasilkan sebanyak 209,56 $\mathrm{m}^{2}$ (Tabel 4). Hasil analisis potensi jejak karbon pada kulit samak yang dihasilkan sebesar $8,08 \mathrm{~kg} \mathrm{CO}_{2}$ eq $/ \mathrm{m}^{2}$.

Tabel 4. Total produk kulit samak per batch

\begin{tabular}{ccc}
\hline $\begin{array}{c}\text { Input (kg } \\
\text { kulit) }\end{array}$ & $\begin{array}{c}\text { Output (kg } \\
\text { kulit) }\end{array}$ & $\begin{array}{c}\text { Total luasan } \\
\text { kulit }\left(\mathbf{m}^{\mathbf{2}}\right)\end{array}$ \\
\hline 1.500 & 421,67 & 209,56 \\
\hline
\end{tabular}

\section{Strategi Penurunan Emisi Karbon pada Proses Penyamakan Kulit}

Tingginya emisi karbon yang dihasilkan selama proses produksi kulit samak merupakan permasalahan yang perlu diselesaikan oleh industri penyamakan kulit. Hal tersebut juga merupakan langkah untuk meningkatkan branding produk industri tersebut. Berdasarkan kajian yang telah dilakukan, upaya yang dapat dilakukan untuk mengurangi emisi karbon dapat dilakukan dengan mengganti sumber pembangkit listrik, merekayasa proses, dan mengganti bahan pendukung yang ramah lingkungan.

Listrik berkontribusi terhadap terbentuknya emisi pada proses penyamakan kulit. Langkah yang dapat dilakukan adalah dengan mengganti sumber listrik yang emisinya lebih rendah dibandingkan dengan listrik yang bersumber pada fosil. Terdapat sumber pembangkit listrik yang emisinya lebih rendah dibandingkan dengan fosil, yakni pembangit tenaga listrik panas bumi, air, sinar matahari dan angin (Djamin, 2010; Gunawan et al., 2010; Saidur et al., 2011; Alimuddin et al., 2018). Namun, penggantian sumber listrik dengan bahan yang ramah lingkungan masih sangat sulit untuk dilakukan karena belum optimalnya pemanfaatan yang dilakukan oleh pemerintah pada saat ini. Berdasarkan data ESDM (2020), target pasokan energi bersih sebesar 23\% pada tahun 2025, sehingga pada saat ini penggunaan energi fosil kurang lebih $80 \%$. Oleh karena itu, langkah perbaikan yang dapat dilakukan adalah dengan menggabungkan beberapa tahapan proses, substitusi bahan kimia, dan penggunaan bahan yang ramah lingkungan, lebih jelasnya dapat dilihat pada Tabel 5.

\section{KESIMPULAN DAN SARAN}

\section{Kesimpulan}

Listrik dan limbah cair berkontribusi terhadap terbentuknya emisi karbon pada proses penyamakan kulit. Namun, limbah cair berkontribusi lebih besar dibandingkan penggunaan listrik selama proses penyamakan. Setiap tahap penyamakan kulit menunjukkan adanya perbedaan jumlah emisi yang terbentuk. Dalam $1 \mathrm{~m}^{2}$ kulit samak menghasilkan emisi karbon sebanyak $8,08 \mathrm{~kg} \mathrm{CO}_{2}$ eq. Strategi yang dapat dilakukan untuk mengurangi emisi karbon pada proses penyamakan kulit, yakni dengan merekayasa proses, substitusi bahan, dan penggunaan bahan yang ramah lingkungan.

\section{Saran}

Saran penelitian ini adalah perlu dilakukan kajian lebih lanjut untuk menganalisis lebih lanjut terkait jejak karbon pada kulit samak dengan menerapkan metode cradle to cradle untuk mengetahui emisi karbon yang sebenarnya dari proses pembuatan kulit samak. 
Tabel 5. Strategi penurunan emisi karbon pada proses penyamakan kulit

\begin{tabular}{|c|c|c|}
\hline Strategi & Keunggulan & Sumber \\
\hline $\begin{array}{l}\text { Subtitusi sumber pembangkit } \\
\text { tenaga listrik }\end{array}$ & $\begin{array}{l}\text { Mereduksi dan mengeliminasi } \\
\text { emisi karbon dari dari penggunaan } \\
\text { listrik selama proses produksi }\end{array}$ & $\begin{array}{l}\text { Armannsson et al., 2005; Djamin } \\
\text { 2010; Gunawan et al., 2010; } \\
\text { Saidur et al., 2011; Aneke et al., } \\
\text { 2011; Alimuddin et al., 2018; }\end{array}$ \\
\hline $\begin{array}{l}\text { Single step unhairing - fiber } \\
\text { opening }\end{array}$ & $\begin{array}{l}\text { Mereduksi waktu proses dan } \\
\text { konsumsi listrik }\end{array}$ & Christopher et al., 2014 \\
\hline $\begin{array}{l}\text { Penggunaan asam organik dan non } \\
\text { amonia pada deliming }\end{array}$ & $\begin{array}{l}\text { Menurunkan dan mengeliminasi } \\
\text { penggunaan amonium sulfat, } \\
\text { menurunkan komponen organik } \\
\text { dalam limbah cair }\end{array}$ & $\begin{array}{l}\text { Zeng et al., 2011; Chowdhury et } \\
\text { al., 2018; Udin et al., 2018; Zeng } \\
\text { et al., 2018; Nugraha } \text { et al., } 2020\end{array}$ \\
\hline $\begin{array}{l}\text { Penggunaan enzim pada single } \\
\text { step unhairing-fiber opening }\end{array}$ & $\begin{array}{l}\text { Mereduksi dan mengeliminasi } \\
\text { penggunaan kalsium hidroksida, } \\
\text { hidrogen sulfida dan amonium } \\
\text { sulfat, mereduksi komponen } \\
\text { organik pada limbah cair }\end{array}$ & $\begin{array}{l}\text { Christopher et al., 2014; de Souza } \\
\text { dan Gutterres, } 2012\end{array}$ \\
\hline Penggunaan enzim pada liming & $\begin{array}{l}\text { Mereduksi penggunaan hidrogen } \\
\text { sulfida dan polutan pada limbah } \\
\text { cair }\end{array}$ & $\begin{array}{l}\text { Dayanandan et al., 2003; Paul et } \\
\text { al., 2016; Wang et al., } 2016\end{array}$ \\
\hline $\begin{array}{l}\text { Mengganti proses sammying } \\
\text { menjadi setting out (mengurangi } \\
\text { kadar air kulit) }\end{array}$ & $\begin{array}{l}\text { Penggunaan gas LPG lebih rendah } \\
\text { emisi dibandingkan dengan listrik } \\
\text { yang bersumber dari fosil }\end{array}$ & $\begin{array}{l}\text { Wawancara dengan pelaku } \\
\text { industri }\end{array}$ \\
\hline
\end{tabular}

\section{UCAPAN TERIMA KASIH}

Penulis mengucapkan terima kasih kepada Kementrian Riset, Teknologi dan Pendidikan Tinggi (Kemristekdikti) Indonesia yang telah membiayai penelitian ini dan memberikan beasiswa PMDSU. Ucapan terima kasih juga disampaikan kepada pihak yang telah membantu dalam pelaksanaan penelitian.

\section{DAFTAR PUSTAKA}

Abdallah L dan El-Shennawy T. 2013. Reducing carbon dioxide emissions from electricity sector using smart electric grid applications. Journal Engginering. 1 8. http://dx.doi.org/10.1155/2013/845051

Alimuddin, Tambunan AH, Machfud, Novianto A. 2018. Analisis emisi $\mathrm{CO}_{2}$ pembangkit listrik panas bumi ulubelu lampung dan kontribusinya terhadap pengembangan pembangkit listrik di provinsilampung.

Journal Natural Resources and Environmental Management.9 (2): $287-304$.

Aneke M, Agnew B, dan Underwood C. 2011. Performance analysis of the Chena binary geothermal power plant. Applied Thermal Engineering. 31: 1825-1832.

Ármannsson H, Fridriksson T, dan Kristjánsson BR. 2005. CO2 emissions from geothermal power plants and natural geothermal activity in Iceland. Geothermal. 34:286-296.

Bello MO, Solarin SA, dan Yen YY. 2018. The impact of electricity consumption on $\mathrm{CO} 2$ emission, carbon footprint, water footprint, ecological footprint: the role of hydropower in an emerging economy. Journal Environmental Management. 219: 218 - 230.

Bhargavi NRG, Jayakumar GC, Sreeram KJ, Rao JR, Nair BU. 2015. Towards sustainable leather production: vegetabel tanning in non - aqueous medium. Journal American Leather Chemists Asociation. 110.

Campos JL, Valenzuela - heredia D, Pedrouso A, Val del Rio A, Belmonte M, Mosquera-corral A. 2016. Greenhouse gases emissions from wastewater treatment plants: minimization, treatment and prevention. Journal Chemisty. 1 12. http://dx.doi.org/10.1155/2016/3796352

Chai C, Zhang D, Yu Y, Feng Y, Wong MS. 2015. Carbon footprint analyses of mainstream wastewater treatment technologies under different sludge treatment scenarios in china. Water. 7: 918 - 938.

Chowdhury MJ, Uddin TM, Razzaq A, Al Mizan, Quadery AH. 2018. Ammonia - free deliming using glycolic acid and EDTA and its effect on tannery effluent and quality of leather. Journal American Leather Chemists Asociation. 113: $212-216$.

Christopher JG, Ganesh S, Palanivel S, Ranganathan M, Jonnalagadda RR. 2014. Cohesive system for enzymatic unhairing and fiber opening: an architecture towards eco-benign pretanning operation. Journal Cleaner Production. $428-$ 436.

Darwin R. 2004. Effect greenhouse gas emissions on world agriculture, food consumption, and economic welfare. Journal Climate Change. 66: $191-238$ 
Dayanandan A, Kanagaraj J, Sounderraj L, Govindaraju R, Rajkumar GS. 2003. Application of an alkaline protease in leather processing: an ecofriendly approach. Journal Cleaner Production. 11: 533 - 536.

De Souza FR dan Gutterres M. 2012. Application of enzyme in leather processing: a comparison between chemical and coenzymatic process. Brazilian Journal of Chemical Engineering. 29 (3): 473 - 481.

Djamin M. 2010. Penelitian penerapan pembangkit listrik tenaga surya dan dampaknya terhadap lingkungan. Jurnal Teknik Lingkungan. 11 (2): $221-225$.

[ESDM] Kementerian Energi dan Sumber Daya Mineral. 2016. Faktor emisi gas rumah kaca (GRK) sistem ketenagalistrikan. Jakarta, Indonesia: Direktorat Jenderal Ketenagalistrikan.

[ESDM] Kementerian Energi dan Sumber Daya Mineral. 2020. Maksimalkan energi bersih: ESDM konversi pembangkit listrik fosil ke EBT. Tersedia pada http://ebtke.esdm.go.id/post/2020/02/04/2468 /maksimalkan.energi.bersih.esdm.konversi.pe mbangkit.listrik.fosil.ke.ebt, [06 Oktober 2020]

Fighir D, Teodosiu C, dan Fiore S. 2019. Environmental and energy assessment of municipal wastewater treatment plants in italy and romania: a comparative study. Water. 11: 1- 13. doi:10.3390/w11081611

Gerardi MH. 2003. The Microbiology of Aerobic Digester. USA: John Wiley \& Sons, Inc.

Gunawan, Santoso DEB, dan Subchan M. 2010. Potensi clean development mechanism pada pembangkit mikrohidro 120 KW. Media Elektronik. 3 (2): $11-21$.

Gupta D dan Singh SK. 2012. Green house gas emissions from wastewater treatment plants: a case study of Noida. Journal Water Sustainiblility. 2 (2): 131 - 139.

Harrould - kolieb E, Huelsenbeck M, Selz V. 2010. Ocean acidification the untold stories. Washington DC (US): OCEANA.

[IEA] International Energy Agency. 2011. CO2 emissions from fuel combustion. Imprimerie Centrale, Luxembourg.

[IPCC] Intergovermental Panel on Climate Change. 2006. IPCC Guidelines for Naional Greenhouse Gas Investories Vol.2: Energy. USA (US): Washington DC.

Ludvik J. 1996. Cleaner tanning technologies. UNIDO report. $18-25$.

Nugraha AW, Suparno O, dan Indrasti NS. 2018. Analisis material, energi dan toksisitas (MET) pada industri penyamakan kulit untuk identifikasi strategi produksi bersih. Jurnal Teknologi Industri Pertanian. 28 (1): 48 - 60.
Nugraha AW, Suparno O, Indrasti NS, Hoerudin. 2020. Free ammonia deliming: effect of tartaric acid addition as a demiling agent on the quality of wet blue and waste water. Tropical Animal Science Journal. 43 (2): 176 $-182$.

Paul T, Jana A, Mandak AK, Mandal A, Das Mohpatra PK, Mondal KC. 2016. Bacterial keratinolitic protease, imminent starter for nextgen leather and detergent industries. Sustainable Chemistry Pharmacy. 3: 8 - 22.

Purwanta W. 2010. Perhitungan emisi karbon dari lima sektor pembangunan berdasarkan metode IPCC dengan verifikasi faktor emisi dan data aktivitas lokal. Jurnal Teknik Lingkungan. 11 (1): $71-77$.

Putt DPS dan Bahtia P. 2002. Working 9 To 5 On Climate Change: An Office Guide .World Resource Institute. Washington DC. 13

Radu AL, Scrieciu MA, dan Caacota DM. 2013. Carbon footprint analysis: towards a projects evaluation model for promoting sustainable development. Procedia Economics and Finance. 6: 353 - 363.

Robescu LD dan Presura E. 2017. Reducing carbon footprint of a wastewater treatment plant using advanced treatment and renewale energy sources. Environmental Enggineering Management Journal. 16 (5): 1055 - 1062.

Saidur R, Rahim NA, Islam MR, Solangi KH. 2011. Environmental impact of wind energy. Renewable and Sustainable Energy Reviews. 15: $2423-2430$

Sobek S, Tranvik LJ, dan Cole JJ. 2005. Temperature independence of carbon dioxide supersaturationin global lakes. Global Biogeochemical Cycles. 19(2)

Suparno O, Covington AD, dan Evans CS. Teknologi baru penyamakan kulit ramah lingkungan: penyamakan kombinasi menggunakan penyamak nabati, naftol dan oksazolidin. Jurnal Teknologi Industri Pertanian. 18(2): 79-84.

Teddlie C dan Yu F. 2007. Mixed methods sampling: a typology with examples. Journal Mixced Method Research.1: 77.

Thangarajan R, Kunhikrishnan A, Seshadri B, Bolan NS, Naidu R. 2012. Greenhouse gas emission from wastewater irrigated soils $\mathrm{Di}$ dalam Bjornlund, Brebbia CA, Wheeler S (ed.), Sustainable irrigation and drainage IV. WIT Press. 168: 225 - 236.

[USEPA] United State Environmental Protection Agency. 2014. Framework for assessing biogenic $\mathrm{CO}_{2}$ emission from stationery sources. Tersedia pada https://www3.epa.gov/climatechange/downlo ads/Framework-for-Assessing-BiogenicCO2-Emissions.pdf, [30 September 2020] 
Uddin TM, Chowdhury MJ, Razzaq A, Al Mizan, Quadery AH. 2018. Ammonia - free deliming using glycolic acid and EDTA and its effect on tannery effluent and quality of leather. Journal Industrial Pollution Control. 34: 1957 - 1960.

Vijayan G, Saravanane, dan Sundararajan T. 2017. Carbon footprint analyses of wastewater treatment systems in puducherry. Computational Water, Energy, and Environmental Engineering . 6: 281 - 303.

Wang Y, Zeng Y, Zhou J, Zhang W, Liao X, Shi B. 2016. An integrated cleaner beamhouse process for minimization of nitrogen pollution in leather manufacture. Journal Cleaner Production. 112: 2 - 8 .

Whittington HW. 2002. Electricity generation: options for reduction in carbon emissions.
Philosophical Transactions of the Royal Society of London A. 360: 1653 - 1668

World Nuclear Association. 2020. Climate changethe science. https://www.worldnuclear.org/focus/climate-change-andnuclear-energy/climate-change-thescience.aspx, [02 Oktober 2020]

Zeng Y, Lu J, Liao X, He Q, Shi B. 2011. Nonammonia deliming using sodium hexametaphospate and boric acid. Journal American Leather Chemists Asociation. 106: $257-263$.

Zeng Y, Wang Y, Song Y, Zhou J, Shi B. 2018. A cleaner deliming process using sodium gluconate for reduction in nitrogen pollution in leather manufacture. Journal American Leather Chemists Asociation . 113: 19-25. 